\title{
Knowledge management practices in technology parks: case study - Technology Park TECNOPUC
}

\section{Práticas de gestão do conhecimento em parques tecnológicos: estudo de caso - Parque Tecnológico TECNOPUC}

ISSN 0104-530X (Print) ISSN 1806-9649 (Online)

\author{
Lucio Abimael Medrano Castillo' \\ Edson Walmir Cazarini ${ }^{2}$ (I)
}

\begin{abstract}
How to cite: Medrano, L. A. C., \& Cazarini, E. W. (2019). Knowledge management practices in technology parks: case
\end{abstract} study - Technology Park TECNOPUC. Gestão \& Produção, 26(3), e3162. https://doi.org/10.1590/0104-530X3162-19

\begin{abstract}
The constant search for competitiveness has become a mandatory practice to ensure the survival and growth of the organization, in this context of fierce competition enterprises, cities, regions and entire countries are seeking ways to ensure its sustainability, anchored in knowledge and constant innovation. The Technology Parks have proved development tools aligned to these new challenges, assisting in technological strengthening and integration of cities, regions and nations in the knowledge economy. These innovation centers, production, dissemination and use of knowledge are intensive, and management becomes imperative. Thus, Knowledge Management meets this need, and although it has achieved a consolidated stage as a research field, its relationship with the Technological Parks was little explored in the literature. Based on the analysis and reflection of these research gaps, this paper aims to propose a set of guidelines for the development of Knowledge Management in Technology Parks. To this end, was developed, validated and applied a data collection instrument in five Technological Park, four in Brazil and one in Spain. The selected case studies were analyzed, identifying initiatives, programs and tools related to knowledge management. Finally, based on these results, was proposed the mentioned guidelines.
\end{abstract}

Keywords: Knowledge management; Technology park; Guidelines.

Resumo: A busca constante pela competitividade tornou-se uma prática imperativa para garantir a sobrevivência e crescimento da organização, nesse contexto de acirrada concorrência empresas, cidades, regiões e países inteiros procuram meios que garantam sua sustentabilidade, ancorados no conhecimento e na constante inovação. Os Parques Tecnológicos têm se mostrado ferramentas de desenvolvimento alinhadas a esses novos desafios, auxiliando no fortalecimento tecnológico e na inserção de cidades, regiões e nações na economia do conhecimento. Nesses centros de inovação, a produção, disseminação e uso do conhecimento são intensivos, e sua gestão torna-se imperiosa. Sendo assim, a Gestão do Conhecimento vem atender essa necessidade, e embora ela tenha alcançado um estágio consolidado como campo de pesquisa, a sua relação com os Parques Tecnológicos foi pouco explorada na literatura. Fundamentado na análise e reflexão dessas lacunas de pesquisa, este trabalho visa o levantamento de práticas de Gestão do Conhecimento sendo desenvolvidas pelo Parque Tecnológico TECNOPUC. Para tal fim, foi desenvolvido, validado e aplicado um instrumento de coleta de dados. O estudo de caso selecionado foi analisado, identificando iniciativas, programas e ferramentas relacionadas à Gestão do Conhecimento.

Palavras-chave: Gestão do conhecimento; Parques tecnológicos; Diretrizes.

\section{Contextualization and justification}

The current organizational environment is characterized by high competitiveness, information production, constant increase of stakeholder requirements and market complexity (Choi et al., 2008; Valenzuela et al., 2008; Medrano \& Cazarini, 2014).
In this world scenario, organizations compete for market slices no longer individually but in a network, continuously seeking innovations, raising their performance through effectiveness, improving the decision-making process, making an organizational

\footnotetext{
${ }^{1}$ Faculdade de Ciências Integradas do Pontal, Universidade Federal de Uberlândia - UFU, Rua 20, 1600, Tupã, CEP 38304-402, Ituiutaba, MG, Brasil, e-mail: medrano@ufu.br

${ }^{2}$ Escola de Engenharia de São Carlos, Universidade de São Paulo - USP, Av. Trabalhador São-Carlense, 400, CEP 13566-590, São Carlos, SP, Brasil, e-mail: cazarini@sc.usp.br
} 
change focused on learning and use of knowledge (Medrano \& Cazarini, 2014).

This competition has reached levels of national economies, in which countries fight for the survival and insertion of their industries in the globalized world market (Jantti \& Jenkins, 2010).

In this context, governments create policies, develop strategies to ensure their survival and sustainable growth - industrial clusters, international partnerships, free trade agreements, strategic strengthening of industries with comparative advantage, technology parks among others.

This study focuses on one of these strategies the, technology Parks (TPs). Knowledge-based economic and technological development centers that integrate scientific-technological research, business and government organizations (Damanpour \& Gopalakrishnan, 2001; Suhaimi \& Yusof, 2006; Steiner et al., 2006).

The TPs have the role of creating an enabling environment for the innovation industry to be born, grow and add value to other economic sectors and society (ANPROTEC, 2008). These are initiatives aimed at organizing an enabling environment for the creation and development of technology-based organizations through the approximation and integration between research institutions, public agents and private initiative (Zouain et al., 2006).

This study approaches the TPs from the Knowledge Management (KM) perspective, considering KM as the means for performance enhancement and value adding to the activities developed by the Park stakeholders.

According to ANPROTEC (2008), a vision of the future of the TPs has as main factor of repositioning the emergence of a new economy based on knowledge, a new concept of Park emerges, better aligned to a reality of Knowledge Society.

According to Harris (2001), this Knowledge Society is the dominant post-industrial economic development paradigm, which originated in the 1980s, with emphasis on the creation and dissemination of knowledge as the main drivers in the economic growth, income distribution, the growing importance of knowledge-based networks within organizations, and the interface between government and citizens in advanced economies.

Thus, Knowledge Management through a set of organizational elements - strategy, culture, structure, people, tools, metrics and processes - encourages the production, sharing and integration of knowledge, with the objective of adding value to the organization and contributing with its goals (Firestone \& McElroy, 2005; Dalkir, 2005).

In this way, the TPs, similar to any other organization, respecting their particularities, identify in KM the means for its improvement and permanence in the current competitive scenario.

Although these two areas of knowledge were widely discussed in the literature independently, the relationship between them was little explored. The main works identified in the scientific community present gaps and opportunities for improvement, which motivate the development of this research, being they (Suhaimi \& Yusof, 2006; Dombrowski, 2006; Grassler \& Glinnikov, 2008; Magalhães, 2009; Mohana, 2011; Rubin et al., 2015):

- The Partial Approach to Knowledge Management.

- Focus of the research with a direction that starts in the Knowledge Management directed to Technology Parks, neglecting practices originating from the TPs that could contribute to the literature of the KM.

- Explanation of limitations and difficulties for the implantation of KM in TPs by the presented researchers, identifying few cases of success.

Realizing these difficulties and the importance of Knowledge Management for Technological Parks, the research problem can be presented through the following question: How should Knowledge Management in Technology Parks be developed? Based on the research problem, the main objective of the work is to colletct Knowledge Management practices, in the specific case, practices being developed by the TECNOPUC Technology Park, identifying concrete and consolidated actions that support new ventures and allow the creation of a set of guidelines for the systematic application of KM in TPs.

\section{Knowledge management}

According to Zabot \& Silva (2002), society lives a historical moment, a rupture of old concepts, paradigms and constant changes, giving rise to the information society or knowledge (Drucker, 1993), network (Castells, 1999), post (De Masi, 2003), or, according to Friedman (2005), to a flat world. In this new society many factors are involved, one of the most important being knowledge, as well as its management, thus raising the interest of knowing its origin and evolution to the present day.

$\mathrm{KM}$ is defined as the management (planning, coordinating, directing, controlling / evaluating) activity of people, structure, processes, tools and other organizational components, with the purpose of adding value to the organization through the production and integration of the knowledge (knowledge management cycle or knowledge process) (McElroy, 2000; Dalkir, 2005; Zheng et al., 2010). 
Skyrme (2013), presents a current scenario of information generation, which in the author's words happens at a prodigious pace, challenging organizations in the processing and use of this information and its transformation into knowledge. In this way new approaches that contribute to the evolution of KM arise, such as Big Data and Analytical Systems.

Based on organizational experiences, two trends are identified in KM literature. The companies that started the implementation of KM in the late 1990s present stages of maturity, in which KM becomes a natural and spontaneous practice of the organization, with increasing success stories and applications in the different business areas. A second convergence is identified, individuals have developed KM practices to add value to their work, reinforcing the spontaneity of the process, no longer being considered an obligation or tool to be used, but a practice with a positive influence on performance (Sedighi \& Jalalimanesh, 2014; Wong et al., 2015).

\subsection{Critical success factors of knowledge management}

Critical Success Factors (CSF) are considered elements of the organization that, when properly worked, guarantee the success of the company and, when neglected, significantly affect performance (Rockart, 1979).

According to Wong (2005) and Wong \& Aspinwall (2005) the CSF for KM represent the activities that should be developed to ensure the success of its implementation within the organization, these authors consider the following: Leadership and support, culture, strategy and purpose, resources, processes and activities, training and education, human capital management, IT, motivational help, organizational infrastructure and metrics.

Medrano (2011), analyzed the main studies on CSF of KM, the author evidences in his research the approach of this topic on different perspectives, identifying CSF for KM in small, medium and large companies, different organizational sectors, local, national and international realities (Table 1).

Recent research on the subject reinforces the importance of KM approach using CSF and enriches understanding of these factors (Table 2).

The CSF identified in the literature were classified according to their similarity, aiming at their delimitation that allows their study and application in this research. Therefore, the following CSF were determined:

\subsubsection{Knowledge Management Strategy}

Based on a systemic and long-term approach, the KM strategy guarantees the sustainability of its implementation and use in the organization, aligned with the organizational strategy. It comprises a vision, mission, objectives, goals and procedures defined for KM. (Choi et al., 2008; Pawlowski \& Bick, 2012; Liophanich, 2014),

\subsubsection{Organizational culture of knowledge}

An organizational culture of knowledge comprises the perspective of those involved in relation to knowledge, its ownership, sharing, prioritization and critical attitude about existing knowledge. It understands the relationship between people, covering factors such as trust, openness, care, cooperation and cohesion. It understands the relationship of people with work, expectations, work climate, intra-entrepreneurship, incentive and motivation (Zheng et al., 2009).

\subsubsection{Organizational structure of knowledge}

The elements of culture comprise the distribution of roles and responsibilities to the members of the company, when speaking in KM these assignments are flexible and relatively unstructured, giving more freedom to members to deal with their demands and tasks, without neglecting the expected results. It comprises the distribution of power of decision, with low centralization and development of empowerment, reflecting in increasingly flat hierarchies, having as unit of work the team. It comprises the communication and transfer of information between the members and areas of the organization, with well-defined and publicized channels, with wide use of all members, generating integration and cohesion (Chen \& Huang, 2007; Cortes et al., 2007).

\subsubsection{Knowledge management team}

According to Medrano \& Cazarini (2014), the organization needs to make a person available for KM functions, in the first stage it may be a mid-level manager, usually the IT or R \& D management that assumes this function, in a second stage a specialist, known in the market with the Knowledge Director or Chief Knowledge Officer (CKO), should be hired / trained, in a third stage a specialized team will be formalized, and in stages of maturity, there will be no more specific people but the participation of all members of the organization of formal natural and spontaneous.

\subsubsection{Knowledge management tools}

Generally treated as IT tools, KM tools comprise IT methodologies, techniques and tools that support KM practices. They are focused on facilitating knowledge processes (creation, dissemination, use), evaluating 
Table 1. Critical success factors of knowledge management.

\begin{tabular}{|c|c|c|}
\hline Author & \multicolumn{2}{|c|}{ Critical success factors } \\
\hline Skyrme \& Amidon (1997) & $\begin{array}{l}\text { - Alignment with business } \\
\text { - KM structure } \\
\text { - Leadership } \\
\text { - Culture }\end{array}$ & $\begin{array}{l}\text { - Continuous learning } \\
\text { - IT } \\
\text { - Knowledge processes }\end{array}$ \\
\hline Davenport (1998) & $\begin{array}{l}\text { - Relationship between } \mathrm{Km} \text { and economic } \\
\text { performance } \\
\text { - Purpose and clear language } \\
\text { - Knowledge structure } \\
\text { - Channels for knowledge transfer }\end{array}$ & $\begin{array}{l}\text { - Organizational culture } \\
\text { - Organizational structe } \\
\text { - Motivational pratice } \\
\text { - Top management support }\end{array}$ \\
\hline Liebowitz (1999) & $\begin{array}{l}\text { - KM strategy } \\
\text { - Knowledge manager } \\
\text { - Repository and ontology of knowledge }\end{array}$ & $\begin{array}{l}\text { - System and knowledge tools } \\
\text { - Culture and incentives for KM } \\
\text { - KM infrastructure }\end{array}$ \\
\hline APQC (1999) & $\begin{array}{l}\text { - KM strategy } \\
\text { - Leadership } \\
\text { - Knowledge culture }\end{array}$ & $\begin{array}{l}\text { - IT } \\
\text { - Metrcis }\end{array}$ \\
\hline Hasanali (2002) & $\begin{array}{l}\text { - Leadership } \\
\text { - KM culture } \\
\text { - KM structure }\end{array}$ & $\begin{array}{l}\text { - KM team } \\
\text { - IT } \\
\text { - Metrics }\end{array}$ \\
\hline Wong (2005) & $\begin{array}{l}\text { - Leadership and support } \\
\text { - Culture } \\
\text { - Purpose and strategy } \\
\text { - Resources } \\
\text { - Process and activities } \\
\text { - Training and education }\end{array}$ & $\begin{array}{l}\text { - Human capital management } \\
\text { - IT } \\
\text { - Motivational help } \\
\text { - Organizational infrastructure } \\
\text { - Metrics. }\end{array}$ \\
\hline Chua \& Lam (2005) & $\begin{array}{l}\text { - IT } \\
\text { - Culture }\end{array}$ & $\begin{array}{l}\text { - Content } \\
\text { - KM project }\end{array}$ \\
\hline Chong \& Choi (2005) & $\begin{array}{l}\text { - Training } \\
\text { - People involvement } \\
\text { Work Team } \\
\text { - Empowerment } \\
\text { - Leadership and commitment of top } \\
\text { management }\end{array}$ & $\begin{array}{l}\text { - Metrics } \\
\text { - Benchmarking } \\
\text { - Knowledge structute } \\
\text { - Knowledge culture } \\
\text { - IT }\end{array}$ \\
\hline Yeh et al. (2006) & $\begin{array}{l}\text { - KM strategy } \\
\text { - Leadership and commitment of top } \\
\text { management } \\
\text { - Culture }\end{array}$ & $\begin{array}{l}\text { - People } \\
\text { - IT }\end{array}$ \\
\hline Jafari et al. (2007) & $\begin{array}{l}\text { - Team work } \\
\text { - Leadership and commitment of top } \\
\text { management } \\
\text { - Organzational structure } \\
\text { - Benchmarking }\end{array}$ & $\begin{array}{l}\text { - Occupational safety and labor } \\
\text { enrichment } \\
\text { - Culture } \\
\text { - Training and learning }\end{array}$ \\
\hline Bishop et al. (2008) & $\begin{array}{l}\text { - Clear definition of KM } \\
\text { - Alignment between KM and } \\
\text { organizational strategy } \\
\text { - K team } \\
\text { - Top management support }\end{array}$ & $\begin{array}{l}\text { - Demonstrate benefits of KM } \\
\text { - Rewards and incentives } \\
\text { - Balance between people e IT }\end{array}$ \\
\hline Chang et al. (2009) & $\begin{array}{l}\text { - KM strategy } \\
\text { - IT } \\
\text { - KM documentation } \\
\text { - Organizational structure }\end{array}$ & $\begin{array}{l}\text { - Human capital assets } \\
\text { - Knowldge processes } \\
\text { - Addition of value and organizational } \\
\text { performance. }\end{array}$ \\
\hline
\end{tabular}


Table 2. Critical success factors of knowledge management 2.

\begin{tabular}{|c|c|c|}
\hline Autor & Critical su & cess factors \\
\hline Aulawi et al. (2009) & $\begin{array}{l}\text { - People } \\
\text { - IT }\end{array}$ & $\begin{array}{l}\text { - Culture } \\
\text { - Structure }\end{array}$ \\
\hline Ajmal et al. (2010) & $\begin{array}{l}\text { - Familiarity with KM } \\
\text { - Coordination between employee and } \\
\text { organizatioanl áreas } \\
\text { - Incentives }\end{array}$ & $\begin{array}{l}\text { - Authority allocated to KM } \\
\text { - Knowledge System } \\
\text { - Culture }\end{array}$ \\
\hline $\begin{array}{l}\text { Valmohammadi } \\
\text { (2010) }\end{array}$ & $\begin{array}{l}\text { - Leadership } \\
\text { - Top management support } \\
\text { - Organizational culture } \\
\text { - KM strategy } \\
\text { - Resource allocation } \\
\text { - KM process } \\
\text { - Human capital management } \\
\text { - Organizational structure }\end{array}$ & $\begin{array}{l}\text { - Metrics } \\
\text { - Training and education } \\
\text { - IT } \\
\text { - Incentive and reward } \\
\text { - Benchmarking }\end{array}$ \\
\hline $\begin{array}{l}\text { Al-Hakim \& } \\
\text { Hassan (2012) }\end{array}$ & $\begin{array}{l}\text { - Human capital management } \\
\text { - IT } \\
\text { - Leadership } \\
\text { - Organizational learning }\end{array}$ & $\begin{array}{l}\text { - Estrategy } \\
\text { - Structure } \\
\text { - Culture }\end{array}$ \\
\hline $\begin{array}{l}\text { Pawlowski \& Bick } \\
\text { (2012) }\end{array}$ & $\begin{array}{l}\text { - Integrated technical infrastrucute } \\
\text { - Knowledge management } \\
\text { - Knowledge structure } \\
\text { - Motivation and commitment } \\
\text { - Knowledge culture } \\
\text { - Management support including resource } \\
\text { allocation, leadership and capacity building } \\
\text { - Metrics } \\
\text { - KM system objectives }\end{array}$ & $\begin{array}{l}\text { - Serach, retrieve and view functions } \\
\text { - Work process that incorporate knowledge } \\
\text { capture and use } \\
\text { - Organizational learning } \\
\text { - Security and protection of knowledge. }\end{array}$ \\
\hline $\begin{array}{l}\text { Hojabri et al. } \\
(2012)\end{array}$ & $\begin{array}{l}\text { - Top management support } \\
\text { - IT } \\
\text { - Metrics } \\
\text { - Organizational culture }\end{array}$ & $\begin{array}{l}\text { - KM strategy } \\
\text { - KM process } \\
\text { - Training }\end{array}$ \\
\hline Liophanich (2014) & $\begin{array}{l}\text { - Top management support } \\
\text { - IT } \\
\text { - Constant activities } \\
\text { - KM tem activities }\end{array}$ & $\begin{array}{l}\text { - Incentives } \\
\text { - Resource allocation } \\
\text { - Business strategy }\end{array}$ \\
\hline $\begin{array}{l}\text { Dominguez \& } \\
\text { Martins (2014) }\end{array}$ & $\begin{array}{l}\text { - Human capital } \\
\text { - KM team } \\
\text { - Culture }\end{array}$ & $\begin{array}{l}\text { - Development and integration of knowledge } \\
\text { - Structure }\end{array}$ \\
\hline $\begin{array}{l}\text { Karami et al. } \\
(2015)\end{array}$ & $\begin{array}{l}\text { - Human capital management } \\
\text { - Organizational culture } \\
\text { - KM strategy } \\
\text { - IT }\end{array}$ & $\begin{array}{l}\text { - Organizational factors (knowledge structure, } \\
\text { knowledge team) }\end{array}$ \\
\hline
\end{tabular}

Source: Prepared by the author.

the effectiveness of KM for the organization and in general on the development of other CSF (Pawlowski \& Bick, 2012).

\subsubsection{Cycles or processes of knowledge management}

According to Medrano \& Cazarini (2014) the knowledge cycle is the operational base of KM, since it is implemented in day-to-day actions, aligning the activities of KM to organizational processes Firestone \& McElroy (2005) argue that all knowledge begins at an individual level, a product of the person's learning, which confronts their current knowledge and seeks to test new theories and truths (problem), this stage is taken at the group level through of discussions and constructive dialogue, thus forming new knowledge.

When individuals recognize a lack of self-knowledge to solve the problem, they search for external sources through an information acquisition process. The generated knowledge is tested, put into practice, 
validated or rejected in a first cycle of improvement, finally obtaining the organizational knowledge.

After this first phase, knowledge is propagated by the community, either spontaneously (sharing) or planned (training, research, diffusion), these statements of (explicit) knowledge, or beliefs (tacit) are stored in repositories and in the minds of workers respectively.

Finally, beliefs and statements are applied to business processes, in a constant search for improvement, generating learning cycles: a) simple, which consists of identifying the error and its solution without questioning beliefs and statements, b) double, which consists of solving the problem by examining and changing the beliefs and statements of knowledge (Argirys \& Schön, 1978).

\subsubsection{Metrics for knowledge management}

The metrics cover methodologies and indicators that provide the organization with information about the practices and results of KM, whether its objectives are being achieved and what impacts it is generating on organizational goals. According to Tan \& Wong (2014) the KM should be evaluated considering its life cycle, IT, organizational culture, strategic processes, mission processes, support processes, personal skills and social relationships. The metrics evaluate all the $\mathrm{KM} \mathrm{CSF}$ and how each is being worked on.

\subsubsection{Collaboration networks}

CSF addressed by Medrano \& Cazarini (2014) after a systemic search of KM, forming part of a proposal for an integrated model for its implementation. Collaboration networks are understood as the organization's effort to form a strong and robust network of knowledge sources, including partners such as universities, research centers, industry organizations, and any external actor that enables them to improve their KM practices and maintain up-to-date knowledge of its members.

\section{Technology parks}

According to Steiner et al. (2006), TPs are innovation environments, instruments deployed in developed and developing countries to boost regional and national economies by adding knowledge content, making these economies more competitive on the international scene. Considered one of the most important initiatives of innovation policy (Vásquez-Urriagoa et al., 2016).

The International Association of Science Parks (IASP) defines them as an organization managed by specialized professionals whose fundamental objective is to increase the wealth and well-being of their community by promoting the culture of innovation and the competitiveness of companies and institutions associated with or installed on it.
Aiming at achieving these objectives, a Technology Park manages and stimulates the flow of knowledge and technology among universities, $R \& D$ institutions, companies and markets; promotes the creation and development of innovative companies through incubation and spin-offs; and provides other high added value services as well as high quality physical space and facilities. According to Hassink \& Hu (2012), the TPs aim to foster the transfer of technology and innovation, thereby increasing the competitiveness of participating companies, regions and even nations.

Still in this context, according to Zouain \& Plonski (2006) the TPs aim:

- Provide value-added services.

- Promote the creation and growth of innovative companies through incubation and spin-off mechanisms.

- Provide high quality infrastructure to promote local development and wealth.

- Promote a culture of innovation and competitiveness.

The first experience in this area was developed in the United States in 1949 at Stanford University, pioneering the concept of Technology Park. This creation would later generate the development of Silicon Valley, which currently groups more than 300 high-tech companies. Subsequently, and based on this first project, the Massachusetts Institute of Technology (MIT) in Boston would generate the project known today as Route 128 (Cooper, 1971; Bellavista \& Sanz, 2009)

Other countries also have very well-developed enterprises in this sector, such as the Malaysian Technology Park, the Entrepreneurship Development Institute and India's Software Technology Parks (STPI), the Hsinchu Science Based Industrial Park and the Taiwan Science Based Industrial Park of Taiwan, Hong Kong Industrial Technology Center, Tsukba and Kazusa Akademia Park of Japan, S \& TR \& D Park of Thailand, KFKI Technology Park of Hungary, Barcelona Technology part of Spain and China with its technology park development program the Shenzhen Science and Industry Park and Beijing Experimental Zone, has more than 53 national parks, 50 regional parks and 30 parks-universities.

In Brazil, according to Associação Nacional de Entidades Promotoras de Empreendimentos Inovadores (ANPROTEC, 2014), the first incentives for the creation of PqTs began in the 1980s, with the creation of the Brazilian Program of Technology Parks by Conselho Nacional de Desenvolvimento Científico e Tecnológico $(\mathrm{CNPq})$, creating the first incubators of Brazilian companies, in São Carlos / SP, Florianópolis / SC, Curitiba / PR, Campina Grande / PB and the Federal District (ANPROTEC, 2008). 
According to ANPROTEC (2014), a study developed by Ministério de Ciência, Tecnologia e Inovação (MCTI) and by Centro de Apoio ao Desenvolvimento Tecnológico da Universidade de Brasília (CDT/UnB), in 2013, 94 Technological Science Parks were registered in Brazil at different stages of development, which shelter 939 companies and generate 29,909 direct jobs. Of the 94 Parks identified, 38 are in the design phase, 28 in the implementation phase and 28 in the operational phase.

In all, investments made in Technology Parks in Brazil total R \$ 5.788 billion from the sectors: business, federal public, state public and municipal public (ANPROTEC, 2014).

\subsection{Actors involved in technology parks}

The knowledge of the actors involved in the PqTs allows to deepen the understanding of its mechanism of operation. Specifically, from the KM perspective, these authors are the main elements to make knowledge cycles happen.
The literature presents the traditional triangulation formed between the government, university and private setor (Gower \& Harris, 1996; Nonaka et al., 2000). The deepening of the research and the description of case studies, evidence additional elements such as: incubators, development agencies, development and investment agencies (Vedovello, 2000; Rosenblum, 2004).

In the context of innovation policy, Avotins \& Jahohnovich (2013) presents the triple helix in which the government is responsible for the political and tax system, guaranteeing the functioning of the system, with the creation and promotion of policies oriented to education and oriented to industry; the university provides human capital and generates a flow of knowledge and the private sector joins with a set of laboratories, young and mature companies. This interaction encourages the creation of TPs, and generates products such as collaborative research contracts, consultancies, clusters and collective tacit knowledge (Figure 1). Vedovello (2000) and Figlioli (2007) describe these actors in detail:

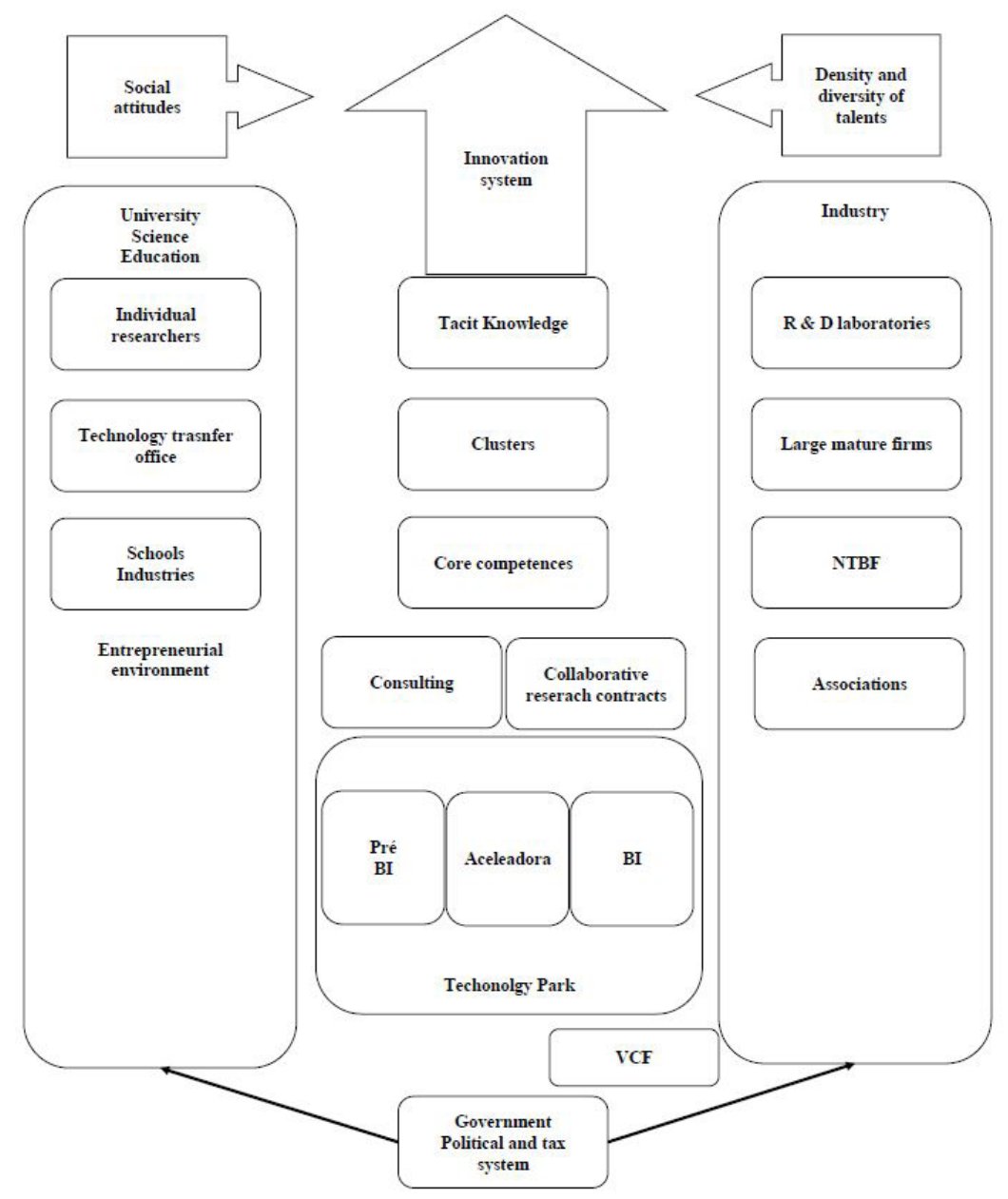

Figure 1. Triple helix in context of innovation policy (Avotins \& Jahohnovich, 2013). 


\subsubsection{University and research institutes}

Aim at the approximation of the productive sector and the increase of revenues by the transfer of technology and intellectual property, in addition to generating training and employment opportunities for students.

\subsubsection{Federal Government and local authorities}

Encourage the creation of Technology Parks to make the regions more competitive and raise the level of their industries.

\subsubsection{Financial agents}

Interested in investing in technology-based companies with rapid growth potential that represent high financial returns.

\subsubsection{Entrepreneurs and academic-entrepreneurs}

The first with the objective of taking advantage of the specialized knowledge of academics and thus raise the technological and competitive level of their products; the second with the objective of applying their research in more commercial areas, both aiming to increase the profits from the interaction and the joint work.

Steiner et al. (2006) complement the presented actors, mentioning the Master Incorporator, group responsible for the real estate project, and the Incubators.

An implicit element in this system is the park's administration, with the main objective of encouraging the relationship between the other actors, has the role of raising funds for the development of the Park, promoting the Technology Park, identifying and attracting resident companies, providing all the important connections between resident companies and universities, assist young and nascent companies, manage the land and buildings of the TPs and carry out the strategic planning to ensure the growth of the Park in relation to investment and partnerships (Steiner et al., 2006; Figlioli, 2007).

\section{Methodology}

According to Gil (2007), the research can be classified according to its nature, problem, objectives and technical procedure.

Regarding its nature, research is classified as applied, aiming at generating knowledge for practical application, aimed at solving specific problems.

Regarding the problem and the aims or objectives of the study, the research is classified as qualitative and of exploratory-descriptive character.
With respect to technical procedures, this study carries out a bibliographic or theoretical conceptual research and a case study. The case study is an exhaustive and in-depth study of one or a few research objects, in a way that allows its broad and detailed knowledge, is an empirical investigation that analyzes a phenomenon within its real life context (Yin, 2004; Gil, 2007).

The technique of data collection used by this study was the semi-structured interview, supported by an interview plan / script composed of a set of guiding questions. This script was validated by three experts. The interview was directed to the director of the Technology Park or representative of the administration, was carried out using Skype as a communication tool, with a duration of 45 minutes. For the analysis of the interview the discourse analysis (DA) was used within the qualitative analysis. Discourse analysis works with meaning and not with the content of the text, a meaning that is not translated but produced, the DA being constituted by the following formulation: ideology + history + language. Since ideology is the subject's position on discourse, history represents the socio-historical context and language the materiality of the text, signs that the subject intends to give (Caregnato \& Mutti, 2006).

\section{Results}

\subsection{Technology Park of PUCRS - TECNOPUC}

TENOPUC's main mission is to create a transdisciplinary research and innovation community through collaboration between academia, companies and government, in order to increase the competitiveness of its actors and improve the quality of life in their communities.

Its main objective is to insert PUCRS directly into the techno-economic-social development process of the region and the country; as detailed objectives the Park seeks:

- To attract research and development companies ( R, D \& I) to work in partnership with the University;

- Promote the creation and development of new technology-based companies;

- Attract research projects and technological development in general;

- Stimulating innovation and business-university interaction;

- Generate a positive synergy between the academic and business environments; 
- To act in a coordinated way with the governmental spheres, particularly in the scope of the Porto Alegre Technopole Project

The Governance of TECNOPUC is formed by the articulation of its Operational Management with its Strategic Management.

The Operational Management, which includes its internal management, is carried out by the board of TECNOPUC, linked to the PUCRS Research and Postgraduate Pro-Rectory, which is responsible for the representation, synergy animation, organization of services provided to resident entities, administration of the real estate and administrative processes of participation and permanence in the enterprise.

The Strategic Management, which defines the philosophies, objectives, strategies and guidelines for the enterprise, is in charge of the Rector's Office of PUCRS, which counts on the advice of the Managing Committee of TECNOPUC, formed by the Pro Rector of Research and Postgraduate (president), Pro-Rector of Extension, Pro-Rector of Administration and Finance, Coordinator of the Legal Prosecution of PUCRS, Director of AGT and the Director of the Park.

Table 3 presents relevant information on TECNOPUC.

\subsection{Knowledge management of TECNOPUC}

TECNOPUC falls within the category of scientific and technological parks linked to the university, a category in which initiatives such as the Barcelona Science Park, the University of Warwick Science Park and the Oxford University Begbroke Science Park.

TECNOPUC is considered one of the main TPs of Brazil, recognized by the researchers of the area as one of the most developed nationally. It is important to note that in the validation process of the research instrument, all experts consulted recognized the relevance of TECNOPUC as a Brazilian TP model. Fact recorded by the award granted by ANPROTEC of the best Technology Park in 2009.

With respect to Knowledge Strategy, definition of a vision, mission and formal objectives for the $\mathrm{KM}$ within the strategic plan of the TECNOPUC, the interviewee acknowledged to have no formal record that evidences strategic thinking of KM.

However, when analyzing the mission and objectives of the Park, key words such as "collaboration" between actors, "partnership" university enterprise, "stimulate" innovation and university-company interaction, "generate" positive synergy between academia and business.

The declaration of these objectives demonstrates the essence of the Park as a mediating and catalyzing instrument of the relations between actors, being thus recognized, strategic thinking of KM but implicitly or without the use of this flag.

Concerning Knowledge Culture, the administration encourages the opening and sharing of knowledge among the actors, being the main focus of the Park the creation of partnerships, this cooperation is materialized through events organized by the park administration, joint and multidisciplinary projects. Even with the presence of competing companies in the Park (HP, Microsoft and Dell), the interviewee affirmed the existence of a predisposition of these companies for the exchange of information and knowledge, being the objective of the administration to facilitate and encourage this type of behavior. A fact realized by the Innovation Center, created in a partnership between PUCRS and Microsoft with the support of DELL, which promotes the qualification

Table 3. Relevant information on TECNOPUC.

\begin{tabular}{|c|c|}
\hline Item & TECNOPUC \\
\hline Heahquarters & Porto alegre e Viamão \\
\hline Number of organizations & 120 \\
\hline Work stations & 6300 \\
\hline Area & $\begin{array}{l}11,5 \text { he (Porto alegre) e } 50 \mathrm{mil} \mathrm{m}^{2} \text { de } \mathrm{A} / \mathrm{C} \\
15 \mathrm{he} \text { (Porto alegre) e } 33 \mathrm{mil} \mathrm{m}^{2} \text { de } \mathrm{A} / \mathrm{C}\end{array}$ \\
\hline Focus & $\begin{array}{l}\text { - Information and communication technology; } \\
\text { - Energy and Environment; } \\
\text { - Life sciences; } \\
\text { - Creative industry. }\end{array}$ \\
\hline Year of creation & 2001 - officially opened in $25 / 08 / 2003$ \\
\hline CEO & Rafael Prikladnicki \\
\hline Number of rooms for shared use & 8 \\
\hline Incubator & RAIAR \\
\hline University & Universidade Federal do Rio Grande do Sul \\
\hline
\end{tabular}

Source: Prepared by the author. 
of organizations and professionals with a view to the efficient and innovative use of IT. The cultural factor is also reinforced by the history of the university and its goal to become an entrepreneurial university, supported by the vision of its greatest leaders, rector and deputy dean, as well as the joint management committee (Spolidoro, 1997).

A consolidated action that supports the Knowledge Culture among other KM CSF is the Technology Management Agency (TMA), which manages the university's relations with companies, government agencies and development agencies in relation to research and technological development projects.

Another concrete initiative of TECNOPUC is the Entrepreneurial Center whose main objective is to stimulate the culture of entrepreneurship in PUCRS by supporting the pre-incubation and incubation of the project and companies.

With respect to the Knowledge Structure, specifically to the communication channels, the Park has a communication team that facilitates the exchange of information and knowledge among the actors, strengthening the internal relationship and covering the communication of the Park with the community, within the TMA previously presented. The interviewee stressed that he had not identified barriers of communication between actors, or actions that limit the performance of this communication team.

Still in the knowledge structure, when talking about centralization or decentralization of decision making, the Park presents a unique leadership in its strategic management represented by the Rectory of PUCRS, but with the presence and advice of a Managing Committee of TECNOPUC formed by Pro- Rector of Research and Postgraduate (president), Pro-Rector of Extension, Pro-Rector of Administration and Finance, Coordinator of the Legal Prosecutor of PUCRS, Director of TMA and the Director of the park. The interviewee commented that one of the elements that facilitated the rapid growth of the Park was the high degree of interaction between these representatives. However, even with the presence of the TMA there is no formal corporate and government representative, thus indicating a lack of governance practices in the decision-making process, although according to the interviewee it is a goal to be achieved in the future.

The operational management of TECNOPUC has a traditional structure, but the registered hierarchy does not limit the communication among the members, including those belonging to the field of Viamão.

When talking about the physical structure of the Park (layout), within a structure of knowledge, TECNOPUC presents a positive grouping of companies, geographic distribution planned to facilitate the communication and cooperation of the actors, was still spoken in the interview the future inauguration of a building which specifically aims to facilitate this communication between the actors, called Inovapucrs.

One initiative already implemented in this area is the Research and Development Institute - Idea, an environment that stimulates the interaction between different academic units and the realization of multidisciplinary projects. Provides support to researchers through assignment of laboratory infrastructure, physical space for projects, development of prototypes and testing and support to the structuring of lawsuits in response public notice.

In addition, the Park offers eight rooms for shared use and a well-defined system of procedures for reserving them, describing the capacity and facilities of each unit (number of seats, tables, availability of audiovisual equipment, among others).

Still in relation to the knowledge structure, TECNOPUC, when falling within the category of Science and Technology Parks linked to the university, shows the benefits of proximity to the source of knowledge.

With regard to Knowledge Management Team, in addition to the presence of the TMA, TECNOPUC has a group called Business Intelligence, which within other functions would have the responsibility of formatting initiatives related to KM. In addition to this team, there is also the communication team, previously presented. A unique team for KM has not been identified, but the actions of these two teams certainly contribute to the development of KM practices. According to Dalkir (2005) in the early stages of KM implementation the organization can delegate traditional functions to company members along with new functions, tasks related to KM.

Referring to the Knowledge Cycle (creation, dissemination and use of knowledge), according to Medrano \& Cazarini (2014), all efforts in the other CSF contribute to its achievement, thus initiatives related to culture, structure, tools and other elements, will encourage the creation, dissemination and use of knowledge, which represents the basis of KM.

Thus, in addition to the initiatives already presented, TECNOPUC has the Synergies Acceleration Program which aims at identifying opportunities for cooperation among the actors of the Park and works towards their realization.

Regarding to KM metrics, the Park does not evaluate KM practices and does not have direct indicators for monitoring results. However, there are indicators of the General Management of the Park, and recognizing the essence of it as a motivating instrument for the interaction between actors involved, it is possible to identify indicators related to KM. According to Spolidoro (1997), in addition to the traditional indicators of Park results, TECNOPUC uses indicators to measure its contribution to socially responsible and competitive regional development and 
the transformation of PUCRS into an entrepreneurial university. The following are important indicators: the number of cooperative R \& D projects and the number of scholarships for undergraduate and graduate students provided by the PUCRS partnership and resident companies.

The KM tools, understood as methodologies, techniques and IT tools, within the framework of TECNOPUC, are listed below:

- Benchmarking

- Raiar Incubator

- Books Tecnopuc 2008 and 2015

- Social media

- Newsletters

- Events

- Corporate Portal

- Joint Projets

With regard to collaboration networks, TECNOPUC has established the following external partnerships:

Germany

- HMWVL-Hessiches Ministerium für Wirtshaft, Verher und Landesent and House of Information Technology

- PRE-Park

\section{Canada}

- GTMA - Greater Toronto Marketing Alliance China

- TUSPARK - Tsinghua University Science Park

\section{EEUU}

- University of South Florida Research Park Italy

- Associazione Trento Rise

United Kingdom

- UKTI - United Kingdom Trade and Investment Russia

- Skolkovo Innovation Center

- Global ICT Parks Network

- Land2Land

\section{Conclusions}

The studied Park carries historical antecedents that determine its current characteristics in relation to the analyzed factors, governance, culture, structure, processes, among others; thus, it is important to consider their particularities and especially the context where they are inserted to thereby understand the object of study systemically.

The identified KM initiatives were described following the KM CSF classification, but it is important to note that the classification was used for structuring the results, with each initiative influencing not only one but several CSF of KM.

The use of the interview as a data collection tool allowed not only the collection of information related to KM practices but also the identification of the interviewee's meaning regarding the subjects addressed, signals captured from facial expressions, tone of voice and emphasis on certain elements of speech.

The following possible considerations about Knowledge Management in Technological Parks can be evidenced: a) there is no dominion over the subject, and yet KM is a little known and applied practice in organizations in general and specifically in Technology Parks; b) the degree of maturity of management of the studied Park did not allow until the moment to focus on these subjects in a planned and concrete way, mainly by the time of creation; c) the Park in its essence is an environment of creation, dissemination and use of knowledge, and the administration naturally performs $\mathrm{KM}$, dispensing with formal planning for this matter.

After analyzing the information and the personal experience experienced in the interview conducted, it can be concluded that the considerations presented in the previous paragraph are valid, although there is awareness of KM but showing a lack of control of the subject by the Park administration. The Park demonstrates a stage of evolution that evidences a constant growth and dynamism of its practices, with future projects very related to KM, although without this label, thus explaining its progress in the area. Parks are centers of knowledge, and management naturally develops KM functions, a fact evidenced in the statement of its missions, objectives and responsibilities, however, formal planning is still required to approach KM systematically.

As future work, it could be proposed an analysis of the Technological Park more comprehensive, including new areas of science, considering financial factors, in search of answers and indicators of the effectiveness of management and $\mathrm{KM}$ of the administration of the Park, analyzing investments made, times execution, billing and profits achieved. 


\section{REFERÊNCIAS}

Al-Hakim, L. A. Y., \& Hassan, S. (2012). Critical success factors of knowledge management, innovation and organizational performance: an empirical study of the Iraqi mobile telecommunication sector. British Journal of Economics, Finance and Management Sciences, 4(1), 31-49.

Ajmal, M., Helo, P., \& Kekäle, T. (2010). Critical factors for knowledge management in project business. Journal of Knowledge Management, 14(1), 156-168. http:// dx.doi.org/10.1108/13673271011015633.

American Productivity and Quality Center -APQC (1999). Knowledge management: Executive summary, Consortium benchmarking study best-practice report. Houston: The American Productivity and Quality Center.

Argirys, C., \& Schön, D. A. Organizational learning: a theory of action perspective. Boston: Addison-Wesley, 1978.

Associação Nacional das Entidades Promotoras de Empreendimentos Inovadores - ANPROTEC (2008). Parques Tecnológicos: Estudo, Análise e Proposições. In Anais do XVIII Seminário Nacional de Parques Tecnológicos e Incubadoras de Empresas (pp. 1-22). Brasília: ABDI.

Associação Nacional das Entidades Promotoras de Empreendimentos Inovadores - ANPROTEC. Centro de Apoio ao Desenvolvimento Tecnológico. Ministério da Ciência, Tecnologia e Inovação (2014). Estudo de Projetos de Alta Complexidade: indicadores de parques tecnológicos. Brasilia: CDT/UnB.

Aulawi, H., Sudirman, I., Suryadi, K., \& Govindaraju, R. (2009). Knowledge sharing behavior, antecedents and their impact on the individual innovation capability. Journal of Applied Sciences Research, 5(12), 2238-2246.

Avotins, C. V., \& Jahohnovich, N. (2013). The changing role of the entrepreneurial university in developing countries: the case of latvia Natalja Jarohnovich technology transfer centre of kurzeme of ventspils university college. Jornal of Higher Education Theory and Practice, 13(2010), 121-148.

Bellavista, J., \& Sanz, L. (2009). Science and technology parks: habitats of innovation: introduction to special section. Science \& Public Policy, 36(7), 499-510. http:// dx.doi.org/10.3152/030234209X465543.

Bishop, J., Bouchlaghem, D., Glass, J., \& Matsumoto, I. (2008). Ensuring the effectiveness of a knowledge management initiative. Journal of Knowledge Management, 4(12), 16-29. http://dx.doi.org/10.1108/13673270810884228.

Caregnato, R. C. A., \& Mutti, R. (2006). Pesquisa qualitativa: análise de discurso versus análise de conteúdo. Florianópolis: Texto Contexto Enferm.

Castells, M. (1999). A sociedade em rede. São Paulo: Paz e Terra.

Chang, M. Y., Hung, Y. C., Yen, D. C., \& Tseng, P. T. Y. (2009). The research on the critical success factors of knowledge management and classification framework project in the Executive Yuan of Taiwan Government. Expert Systems with Applications, 36(3), 5376-5386. http://dx.doi.org/10.1016/j.eswa.2008.06.060.

Chen, J. C., \& Huang, W. J. (2007). How organizational climate and structure affect knowledge management: the social interaction perspective. International Journal of Information Management, Amsterdam, 27(2), 104118. http://dx.doi.org/10.1016/j.ijinfomgt.2006.11.001.

Choi, B., Poon, K. S., \& Davis, G. J. (2008). Effects of knowledge management strategy on organizational performance: a complementarity theory-based approach. OMEGA: The International Journal of Management Science, 36(2), 235-251. http://dx.doi.org/10.1016/j. omega.2006.06.007.

Chong, S. C., \& Choi, Y. S. (2005). Critical factors in the successful implementation of knowledge management. Journal of Knowledge Management Practice, 6(1), 234-258.

Chua, A., \& Lam, W. (2005). Why KM projects fail: A multicase analysis. Journal of Knowledge Management, 9(3), 6-17. http://dx.doi.org/10.1108/13673270510602737.

Cooper, A. C. (1971). The founding of technologically-Based Firms. Milwaukee: The Center for Venture Management.

Cortes, C. E., Patronicio, Z. S., \& Eva, P. O. (2007). Organizational structure features supporting knowledge management processes. Journal of Knowledge Management, 11(4), 45-57. http://dx.doi.org/10.1108/13673270710762701.

Dalkir, K. (2005). Knowledge management in theory and practice. Burlington: Elsevier Butterworth- Heinemann.

Damanpour, F., \& Gopalakrishnan, S. (2001). The Dynamics of the Adoption of Product and Process Innovations in Organizations. Journal of Management Studies, 38(1), 45-65. http://dx.doi.org/10.1111/1467-6486.00227.

Davenport, T. H. (1998). Ecologia da informação: por que só a tecnologia não basta para o sucesso na era da informação. São Paulo: Futura.

De Masi, D. (2003). A sociedade pós-industrial. São Paulo: SENAC.

Dombrowski, C. A. (2006). Gestão do conhecimento em parques tecnológicos: um estudo de caso único (Dissertação de mestrado). Faculdade de Administração, Contabilidade e Economia, Pontifícia Universidade Católica do Rio Grande do Sul, Porto Alegre, $113 \mathrm{f}$.

Dominguez, R. V. G., \& Martins, M. F. (2014). Mapping the organizational factors that support knowledge management in the Brazilian automotive industry. Journal of Knowledge Management, 18(1), 152-176. http://dx.doi.org/10.1108/JKM-08-2013-0300.

Drucker, P. (1993). Sociedade pós-capitalista. São Paulo: Pioneira.

Figlioli, A. (2007). Perspectivas de financiamento de parques tecnológicas: um estudo comparativo (Dissertação de 
mestrado). Departamento de Administração da Faculdade de Economia, Administração e Contabilidade de Ribeirão Preto, Universidade de São Paulo, Ribeirão Preto.

Firestone, J. M., \& McElroy, M. K. (2005). Doing knowledge management. The Learning Organization, 12(2), 189212. http://dx.doi.org/10.1108/09696470510583557.

Friedman, T. (2005). The world is flat: a brief history of the twenty-first century. New York: Farrar, Straus, and Giroux.

Gil, A. C. (2007). Métodos e técnicas de pesquisa social (5a ed.). São Paulo: Atlas.

Gower, S., \& Harris, F. (1996). Evaluating British science parks as property investment opportunities. Journal of Property Valuation \& Investment, Bradford, 14(2), 24-37. http://dx.doi.org/10.1108/14635789610112646.

Grassler, A., \& Glinnikov, R. (2008). Knowledge transfer in science parks (MSc. Thesis). Baltic Business School, University of Kalmar.

Harris, G. R. (2001). The Knowledge-based economy: intellectual origins and new economic perspectives. Interntional Journal of Management Reviews, Malden, 4(1), 21-40. http://dx.doi.org/10.1111/1468-2370.00052.

Hasanali, F. (2002). Critical Success Factors of Knowledge Management. Retrieved in 2014, December, from http://www.providersedge.com/docs/km_articles/ Critical_Success_Factors_of_KM.pdf

Hassink, R., \& Hu, X. (2012). Specialisation to diversification in science and technology parks. World Technopolis Association, WTR, 1(1), 6-15. http://dx.doi.org/10.7165/ wtr2012.1.1.6.

Hojabri, R., Borousan, E., \& Manafi, M. (2012). Impact of using telemedicine on knowledge management in healthcare organizations: a case study. African Journal of Business Management, 6(4), 1604-1613.

Jafari, M., Akhavan, P., Rezaee Nour, J., \& Fesharaki, M. N. (2007). Knowledge management in Iran aerospace industries: a study on critical factors. Aircraft Engineering and Aerospace Technology: An International Journal, 79(4), 375-389. http://dx.doi.org/10.1108/00022660710758240.

Jantti, M., \& Jenkins, S. P. (2010). Examining tha impact of Macro-Economic conditions on income inequality. The Journal of Economic Inequality, 8(2), 221-240. http://dx.doi.org/10.1007/s10888-009-9113-8.

Karami, M., Alvani, S. M., Zare, H., \& Kheirandish, M. (2015). Determination of critical success factors for knowledge management implementation, using qualitative and quantitative tools (Case study: Bahman Automobile Industry). Iranian Journal of Management Studies, 8(2), 181-201.

Liebowitz, J. (1999). Key ingredients to the success of an organization's knowledge management strategy. Knowledge and Process Management, 6(1), 37-40. http://dx.doi. org/10.1002/(SICI)1099-1441(199903)6:1<37::AIDKPM40>3.0.CO;2-M.
Liophanich, C. (2014). An investigation of knowledge management implementation: multiple case study in mobile telecommunication industry. Journal of Industrial and Intelligent Information, 2(2), 159-163. http://dx.doi. org/10.12720/jiii.2.2.159-163.

Magalhães, A. B. V. B. (2009). Estrutura de serviços do conhecimento em parques científicos e tecnológicos - Incrementando a relação empresa - Universidade Centros de pesquisa (Tese de doutorado). Instituto de Pesquisas Energéticas e Nucleares (Autarquia Associada à Universidade de São Paulo), São Paulo.

McElroy, M. W. (2000). The new knowledge management. Knowledge and Innovation: journal of the KMCI, 1(1), 43-67.

Medrano, L. A. C. (2011). Modelo integrado para a implantação e desenvolvimento da gestão do conhecimento (Dissertação de mestrado). Escola de Engenharia de São Carlos, Universidade de São Paulo, São Carlos.

Medrano, L. A. C., \& Cazarini, E. W. (2014). Integrated model for implementation and development of knowledge management. Knowledge Management Research and Practice, 14, 1-16.

Mohana, F. (2011). Avaliação de práticas de gestão do conhecimento de parques tecnológicos: uma proposta para apoio à gestão pública (Tese de doutorado). Universidade Federal de Santa Catarina, Florianópolis.

Nonaka, I., Toyama, R., \& Konno, N. (2000). SECI, Ba and Leadership: a unified model of dynamic knowledge creation. Long Range Planning, 33(1), 5-34. http:// dx.doi.org/10.1016/S0024-6301(99)00115-6.

Pawlowski, J., \& Bick, M. (2012). The global knowledge management framework: towards a theory for knowledge management in globally distributed settings. Electronic Journal of Knowledge Management, 10(1), 92-108.

Rockart, J. (1979). Chief executives define their own information needs. Harvard Business Review, 57(2), 81-93. PMid:10297607.

Rosenblum, L. (2004). Profiting from research. American School \& University, Overland Park, 77(3), 334-337.

Rubin, T. H., Aas, T., \& Stead, A. (2015). Knowledge flowin Technological Business Incubators: evidence from Australia and Israel. Technovation, 41-42, 11-24. http://dx.doi.org/10.1016/j.technovation.2015.03.002.

Sedighi, M., \& Jalalimanesh, A. (2014). Mapping research trends in the field of knowledge management. Malaysian Journal of Library \& Information Science, 19(1), 71-85.

Skyrme, D. J. (2013). The seven ages of information \& knowledge management. Retrieved in 2014, December, from http://www.skyrme.com/kmarticles/7ikm.pdf

Spolidoro, R. (1997). A sociedade do conhecimento e seus impactos no meio urbano. In G. G. Paladino \& L. A. Medeiros (Org.). Parques tecnológicos e meio urbano. Brasília: Anprotec. 
Steiner, J. E., Cassim, M. B., \& Robazzi, A. C. (2006). Parques tecnológicos: ambientes de inovação. Estudos Avançados, São Paulo, 15(5), 24-35.

Suhaimi, S., \& Yusof, I. (2006). Technology parks, knowledge transfer and innovation: the case of Malaysia's Information and Communication Technology (ICT) small and medium enterprises. International Journal of the Information Systems for Logistics and Management, 1(2), 133-142.

Tan, L. P., \& Wong, K. Y. (2014). Importance of knowledge protection in knowledge management and its classification of approaches. In Annals of the 23rd International Business Information Management Association Conference. Valencia: IBIMA.

Valenzuela, B. M., Sanchez-Schmitz, G., Perez-Soltero, A., Rubio, F. M., \& Palma, J. (2008). Defining the problem: key element for the success of knowledge management. Knowledge Management Research \& Practice, Hampshire, 6(5), 322-333. http://dx.doi. org/10.1057/kmrp.2008.22.

Vásquez-Urriagoa, A. R., Andrés Barge-Gilb, A., \& Ricoa, A. M. (2016). Science and Technology Parks and cooperation for innovation: empirical evidence from Spain. Research Policy, 45(1), 45. http://dx.doi. org/10.1016/j.respol.2015.07.006.

Vedovello, C. (2000). Aspectos relevantes de parques tecnológicos e incubadoras de empresas. Revista do BNDES, 7(14), 273-300.

Wong, K. Y., \& Aspinwall, E. (2005). Knowledge management: case studies in SMEs and evaluation of an integrated approach. Journal of Information \& Knowledge Management, 4(2), 95-111. http://dx.doi. org/10.1142/S0219649205001079.

Wong, K. Y., Tan, L. P. \& Lee, C. S. (2015). Knowledge Management performance: measures, approaches, trends and future directions. Information Science \& Library Science, 31(3), 239-257.
Wong, Y. K. (2005). Critical success factors for implementing knowledge management in small and medium enterprises. Industrial Management \& Data Systems, 105(3), 261-279.

Yeh, Y. J., Lai, S. Q., \& Ho, C. T. (2006). Knowledge management enablers. Industrial Management \& Data Systems, 6(106), 793-810. http://dx.doi. org/10.1108/02635570610671489.

Yin, R. K. (2004). The Case Study Anthology. Thousand Oaks: Sage Publication Inc.

Zabot, J. B. M., \& Silva, L. C. M. (2002). Gestão do conhecimento: Aprendizagem e tecnologia construindo a inteligência coletiva. São Paulo: Atlas.

Zheng, M. L., Bao, G. M., \& Qian, Y. Y. (2009). Employee commitment, knowledge sharing and knowledge integration: an empirical study of professional staffs in chinese firms. In PICMET 09 - Technology Management in the Age of Fundamental Change. Portland: IEEE. http://dx.doi.org/10.1109/PICMET.2009.5262025.

Zheng, W., Yang, B., \& Mclean, G. N. (2010). Linking organizational culture, structure, strategy, and organizational effectiveness: mediating role of knowledge management. Journal of Business Research, 63(7), 763-771. http:// dx.doi.org/10.1016/j.jbusres.2009.06.005.

Zouain, D., Damião, D., \& Catharino, M. (2006). Parque Tecnológico de São Paulo: as especificações do projeto no contexto de uma Política Pública Local. Locus Cientifico, 1(1), 4-9.

Zouain, D. M., \& Plonski, G. A. (2006). Parques tecnológicos: planejamento e gestão. Brasília: ANPROTEC.

Skyrme, D., \& Amidon, D. (1997). The knowledge agenda. Journal of Knowledge Management, 1(1), 27-37. http:// dx.doi.org/10.1108/13673279710800709.

Valmohammadi, C. (2010). Identification and prioritization of critical success factors of knowledge management in Iranian SMEs: an experts' view. African Journal of Business Management, 4(6), 915-924. 